\title{
Interpretation of borehole impulse tests at Haut Glacier d'Arolla, Switzerland
}

\author{
Bernd Kulessa, Bryn Hubbard \\ Centre for Glaciology, Institute of Earth Studies, University of Wales, Aberystwyth, Ceredigion Sr23 3DB, Wales
}

\begin{abstract}
One hundred and sixteen impulse tests were conducted in a dense borehole array at Haut Glacier d'Arolla, Switzerland, during July and August 1995. Impulsetest response pressure oscillations reveal marked variations in three parameters: relative amplitude decay, oscillation frequency and net water-level displacement. Analysis of response signals from water-filled boreholes indicates that (i) responses from individual boreholes are reproducible over some tens of minutes; (ii) responses are similar, but not identical, for slug insertion ("slug tests") and removal ("bail tests"); (iii) signal amplitude decay varies with the depth at which the recording pressure transducer is located in a borehole; and (iv) coherent minima in all three response parameters coincide with the location of a known preferential, subglacial water-flow pathway. This correspondence suggests, first, that water-filled and non-fluctuating boreholes have established a link to the subglacial aquifer at Haut Glacier d'Arolla and, secondly, that locally transmissive basal sediments may be identified by relatively low response-signal frequencies, response-signal decays and net water-level displacements. Impulse testing water-filled boreholes therefore has the capacity to provide information relating to the local hydrogeological properties of subglacial aquifers.

In 43 cases, water levels in boreholes adjacent to those being tested were recorded in order to identify possible subglacial linkages. No such connections were detected.
\end{abstract}

\section{INTRODUCTION}

Subglacial meltwater drainage systems may be classified as either arborescent or non-arborescent. Arborescent drainage via subglacial channels is hydraulically effective and characterised by an inverse relation between steady-state meltwater discharge and pressure (Röthlisberger, 1972; Nye, 1973). In contrast, non-arborescent or distributed systems are relatively ineffective, lubricate extensive areas of the glacier bed and are generally characterised by a positive relationship between steady-state discharge and pressure. Nonarborescent drainage configurations include meltwater films (e.g. Weertman, 1957) and linked cavities (e.g. Walder, 1986) at hard-bedded glaciers, and pore-water flow (e.g. Clarke, 1987) and flow via "canals" within or above the sediment body (Walder and Fowler, 1994) at soft-bedded glaciers. In reality, many valley glaciers may be underlain by patches of sediments interspersed with bedrock, and drained by temporally varying hydrological configurations (e.g. Harper and Humphrey, 1995). Elucidating the hydraulic character, structure and evolution of such subglacial drainage systems represents a research priority, since these characteristics may have direct implications for the motion of temperatebased glaciers and their response to climate change. Borehole response testing may provide one means of deriving such information.

Analysis of glacier borehole response tests is based on the assumption that water in a borehole drilled to the glacier bed is in communication with the subglacial hydrological system (considered as an aquifer). Impulse testing involves artificially disrupting a steady-state borehole water level and monitoring its recovery to equilibrium. The nature of this response is regulated by, and therefore reflects, the hydrogeological properties of the subglacial aquifer to which the borehole is connected. Water-level disruption may conveniently be induced by the rapid insertion (slug test) and removal (bail test) of a sealed pipe, commonly referred to as a slug. Borehole response tests therefore provide a relatively simple and effective means of investigating glacial hydraulic systems.

Stone (1993) and Stone and Clarke (1993) used borehole response tests to investigate the hydrogeological properties of unconsolidated sediments beneath Trapridge Glacier, Canada. These authors modelled impulse-test records in terms of aquifer transmissivity, compressibility and hydraulic conductivity. While these parameters could not be investigated in isolation, field data suggested the presence of a highly transmissive, but spatially and temporally variable, subglacial water-flow system at Trapridge. In the present study we adopt a more empirical approach to impulse testing, reporting on 116 tests conducted in a dense borehole array overlying a melt-season, subglacial channel at Haut Glacier d'Arolla, Switzerland. Each impulse test comprised slug insertion (slug test) and removal (bail test). Testing was conducted during July and August 1995, focusing on (i) the forms of impulse-test responses monitored in different boreholes; (ii) method-related influences on impulse-test responses; and (iii) spatial variability in response signals relative to a known subglacial channel.

\section{FIELD SITE AND METHODOLOGY}

Haut Glacier d'Arolla is a small valley glacier located at the 


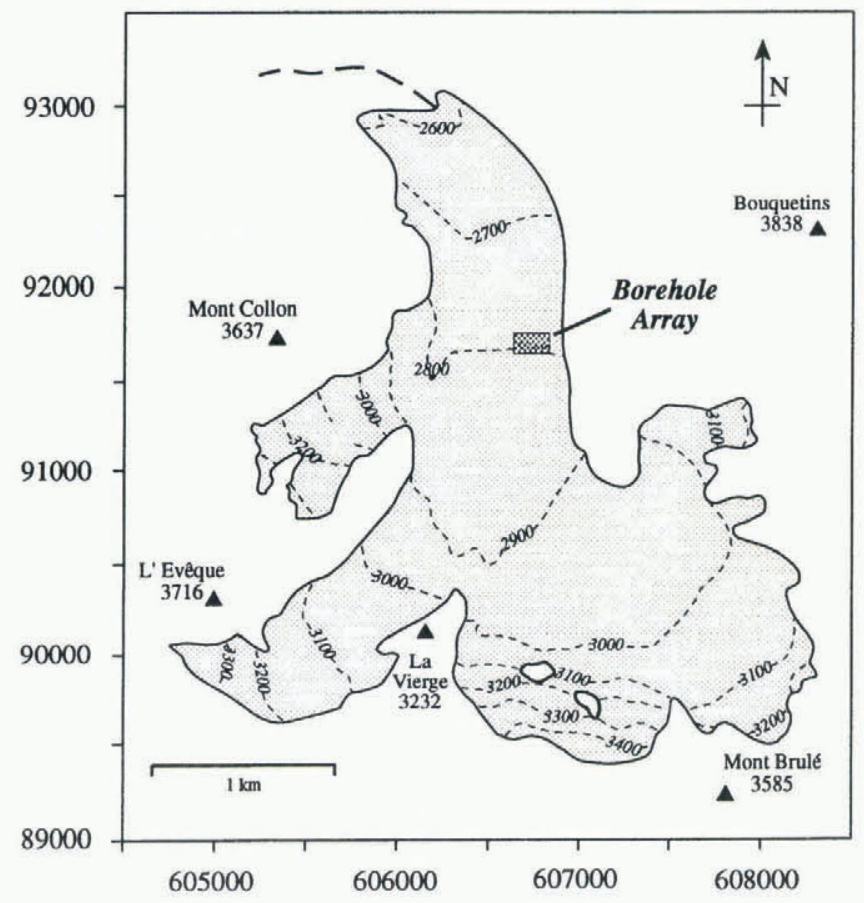

Fig. 1. The location of the borehole array at Haut Glacier d'Arolla, Switzerland.

head of Val d'Hérens, Valais, Switzerland (Fig. 1). It has a surface area of $\sim 6.3 \mathrm{~km}^{2}$ and extends from $\sim 2560 \mathrm{~m}$ a.s.l. at its snout to $\sim 3500 \mathrm{~m}$ a.s.l. at its headwall. In 1995, a dense array of boreholes was drilled $\sim 1.5 \mathrm{~km}$ from the terminus in an area considered to be underlain principally by unconsolidated sediments (Hubbard, 1992; Fig. 2). The borehole array spans a major melt-season subglacial drainage channel, identified on the basis of hydraulic reconstructions by Sharp and others (1993) and Hubbard and others (1995).

Boreholes drilled to the glacier bed are frequently classified as either "connected" or "unconnected" to the subglacial hydrological system (e.g. Hodge, 1976, 1979; Fountain, 1994; Smart, 1996). The former are generally identified by diurnally fluctuating water levels that are assumed to connect with hydraulically active regions of the glacier bed. "Unconnected" boreholes are characterised by constant, highstanding water levels and are assumed to be isolated from the subglacial drainage system. However, boreholes that penetrate the beds of temperate glaciers must be connected to some form of drainage system, since these bases are predominantly at the pressure-melting point. Indeed, Murray and Clarke (1995) recently recorded and analyzed pressure

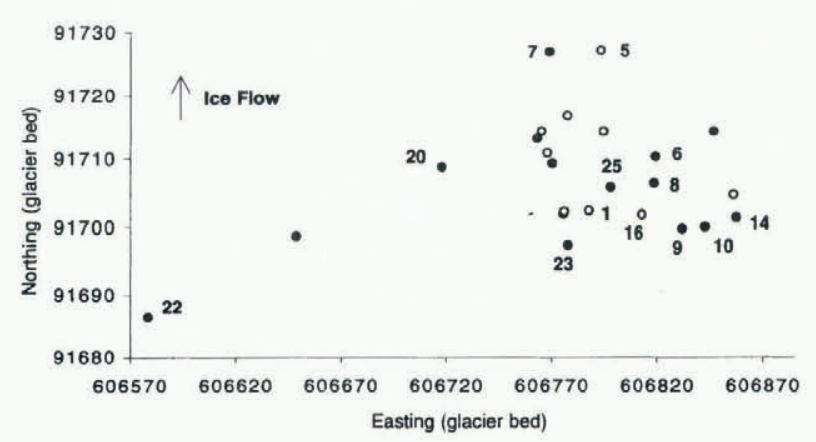

Fig. 2. The 1995 borehole array. Open and closed circles respectively represent fluctuating and water-filled boreholes. Impulse-tested boreholes are listed in Table 1. fluctuations in sealed, high-standing boreholes at Trapridge Glacier, Canada, and suggested that pressures (if not levels) in these boreholes responded to changes in subglacial hydraulics at a diurnal time-scale. Thus, since apparently "unconnected" boreholes may, in fact, have established a link to the subglacial drainage system (however poor), we refer to them in the present study as water-filled. For consistency we refer to apparently "connected" boreholes as fluctuating. A variety of methods was used to ascertain borehole status, including in situ automated sensor records, regular electrical conductivity profiling and visual checking of high-standing water levels. The spatial distribution of fluctuating and water-filled boreholes, along with those that were impulse tested, is presented in Figure 2.

Impulse-test response signals are generally characterised by a series of oscillations that decay to the initial, or a new, equilibrium water level (Stone and Clarke, 1993). Responses were monitored in the present study by sensors placed (unless otherwise stated) $\sim 5 \mathrm{~m}$ below the water surface at a frequency of $64 \mathrm{~Hz}$ on Campbell Scientific CR10 data loggers. In order to characterise these signals, three response parameters have been identified: (i) amplitude decay, (ii) oscillation frequency, and (iii) net water-level displacement (Fig. 3). Net water-level displacement is considered to be related to aquifer storativity, although imprecisely (e.g. Harvey, 1992). Patterns of amplitude decay in different boreholes were too diverse to be described by an exponential function without overinterpreting record complexity. Thus, we propose a simple means of comparing amplitude decays in different boreholes, by defining relative amplitude decay $\left(A_{\text {rel }}\right)$ as:

$$
A_{\text {rel }}=\frac{A_{1}-A_{3}}{A_{1}}
$$

where $A_{1}$ and $A_{3}$ are respectively the amplitudes of the first
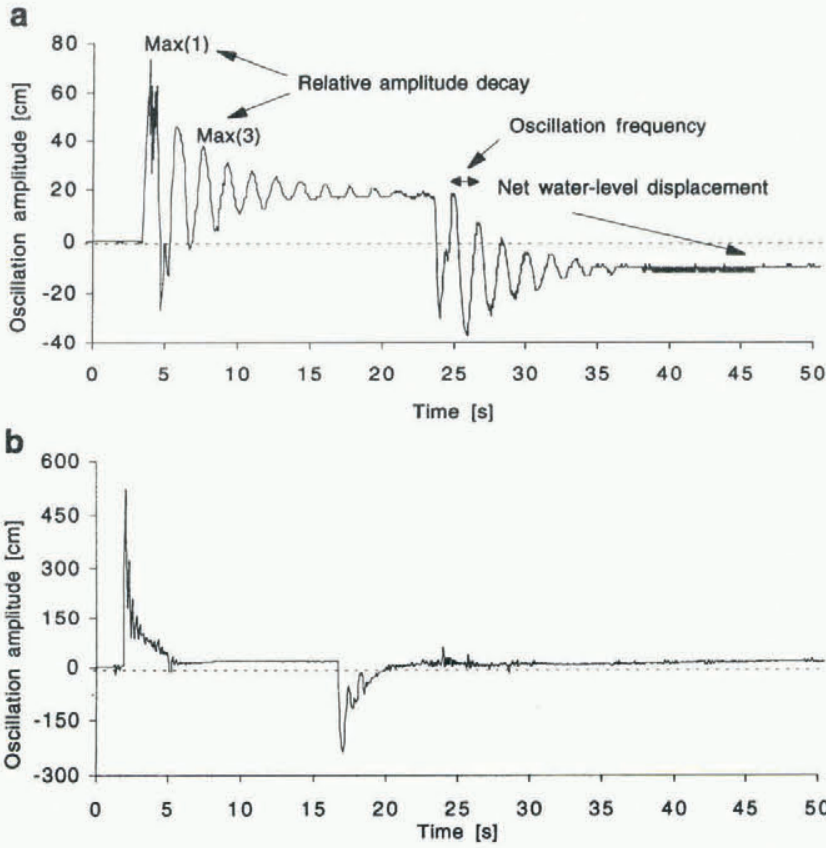

Fig. 3. Typical impulse-test responses from (a) water-filled boreholes and (b) fluctuating boreholes. Note the less welldefined responses from the fluctuating borehole. Relative amplitude decay, oscillation frequency and net water-level displacement are defined in the text. 
Table 1. Boreholes tested in the study

\begin{tabular}{|c|c|c|}
\hline Borehole No. & Number of tests & Date (Julian day) \\
\hline 1 & 4 & 222 \\
\hline 5 & 4 & 212 \\
\hline 5 & 2 & 227 \\
\hline 5 & 2 & 230 \\
\hline 6 & 2 & 230 \\
\hline 6 & 10 & 239 \\
\hline 7 & 2 & 221 \\
\hline 7 & 4 & 229 \\
\hline 8 & 4 & 221 \\
\hline 8 & 4 & 222 \\
\hline 8 & 2 & 230 \\
\hline 8 & 8 & 237 \\
\hline 9 & 4 & 230 \\
\hline 9 & 4 & 239 \\
\hline 10 & 4 & 230 \\
\hline 10 & 8 & 239 \\
\hline 14 & 2 & 229 \\
\hline 14 & 4 & 230 \\
\hline 16 & 4 & 224 \\
\hline 20 & 20 & 220 \\
\hline 22 & 6 & 229 \\
\hline 23 & 8 & 224 \\
\hline 25 & 4 & 227 \\
\hline
\end{tabular}

and third major oscillations following disturbance (Fig. 3a). The first and the third oscillations were chosen in order to cater for the irregularity commonly observed in the first two signal-response cycles, whilst eliminating the impact of increasing noise from later, lower-amplitude oscillations. Frequency was also determined over the first three responsesignal oscillations. Since oscillations induced by an impulse test usually ceased within $10 \mathrm{~s}$ of disturbance, net water-level displacement is defined as the mean water level $10-15 \mathrm{~s}$ after the bail test, minus the steady-state water level recorded prior to the corresponding slug test.

One hundred and sixteen tests were conducted in the present study (Table 1). Of these, 43 were also monitored simultaneously in nearby (secondary) boreholes in order to investigate potential subglacial connections between neighbouring boreholes. Ninety-one of the tests were conducted in water-filled boreholes, largely reflecting the logistical difficulties involved with testing low-standing water levels. Much of our analysis is therefore based on tests conducted in water-filled boreholes. Test responses in fluctuating boreholes are the subject of ongoing research and will be published in a later paper.

\section{RESULTS}

\section{Comparison of response signals from water-filled and fluctuating boreholes}

Typical impulse-test responses recorded in water-filled and fluctuating boreholes are given in Figure 3. As expected, signals generally take the form of a series of damped oscillations around the new water level. However, while relative amplitude decay and oscillation frequency are clearly identified in water-filled boreholes, the signals recorded from the fluctuating holes are less clearly defined and more irregular. In the following analysis we therefore treat impulse-test responses from water-filled and fluctuating holes separately. Water-level displacements in fluctuating boreholes are typi-
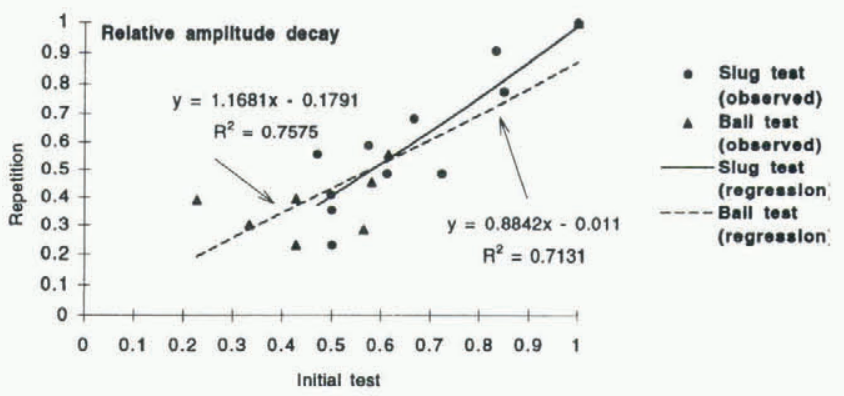

b

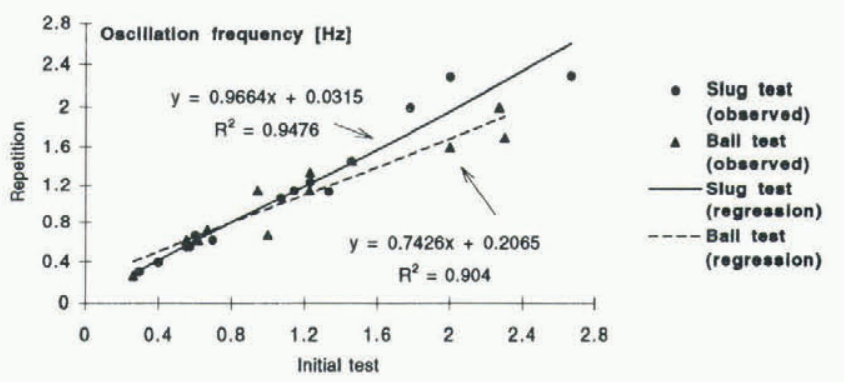

c

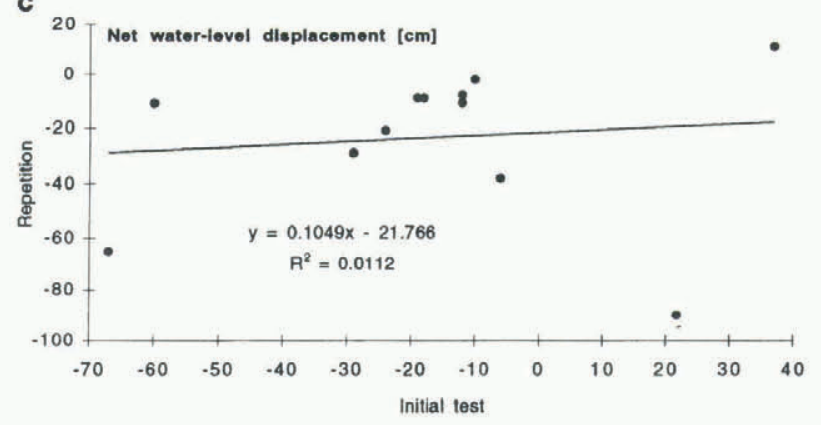

Fig. 4. Repeated impulse-test responses plotted against initial responses: (a) relative amplitude decay, (b) oscillation frequency, and (c) net water-level displacement. Note that (c) is less stable than $(a)$ or $(b)$. Least-squares linear regression statistics are presented.

cally an order of magnitude greater than those in waterfilled holes (Fig. 3).

\section{Response-signal reproducibility}

Repeated impulse tests in water-filled boreholes indicate that relative amplitude decays and oscillation frequencies are reproducible over some tens of minutes (Fig. 4). Linear regression of initial test signals against repeat test signals reveals correlation statistics $\left(R^{2}\right)$ of 0.75 (slug) and 0.71 (bail) for relative amplitude decay (Fig. 4a) and 0.95 (slug) and 0.90 (bail) for oscillation frequency (Fig. 4b). Marked temporal variations in these response parameters from a given borehole may therefore reflect temporal variability in the hydraulic system to which that borehole is connected. In contrast, only a weak correlation $(0.01)$ is recorded between repeated net water-level displacements (Fig. 4c).

Comparison of slug and bail responses for each test series indicates consistent, but not identical, relative amplitude decays $\left(R^{2}=0.57\right.$; Fig. $\left.5 \mathrm{a}\right)$ and oscillation frequencies $\left(R^{2}=\right.$ 0.88 ; Fig. 5 b). We therefore treat slug- and bail-test response parameters separately.

\section{Method-related variability in response signals}

Three test series were carried out with pressure transducers 
a

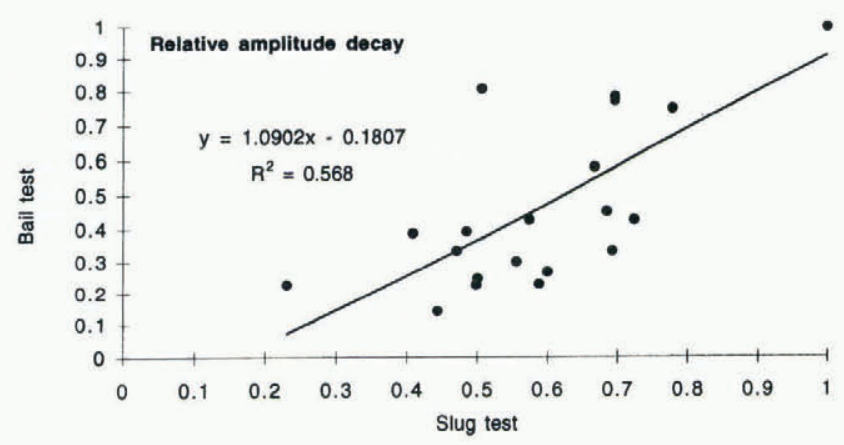

b

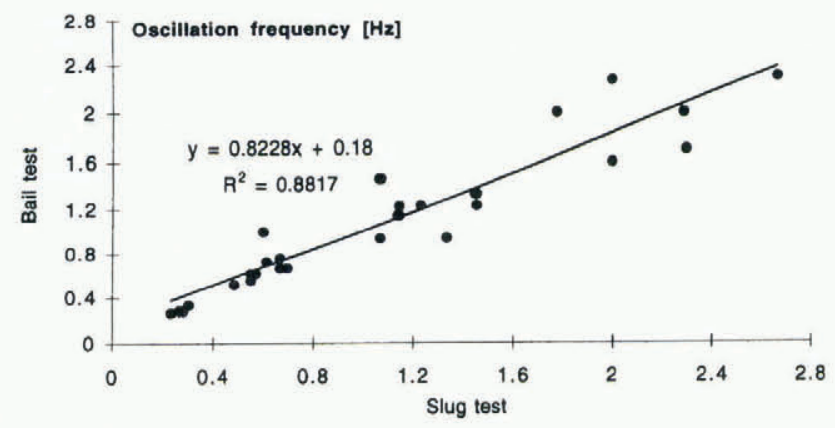

Fig. 5. Comparison of (a) relative amplitude decays and ( $b$ ) oscillation frequencies, recorded during slug and bail tests. Least-squares linear regression statistics are presented.

located at different depths in (water-filled) boreholes in order to investigate the influence of transducer depth on test responses. Tests were carried out at incremental sensor depths of $10 \mathrm{~m}$, both as the sensor was lowered to the glacier bed and as it was subsequently raised back to the ice surface.

a

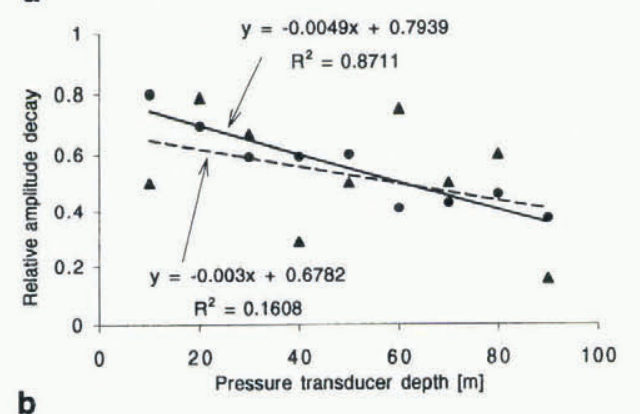

- Slug test (observed)

- Ball test (observed) Slug test (regression) -Bail test
(regression)

b

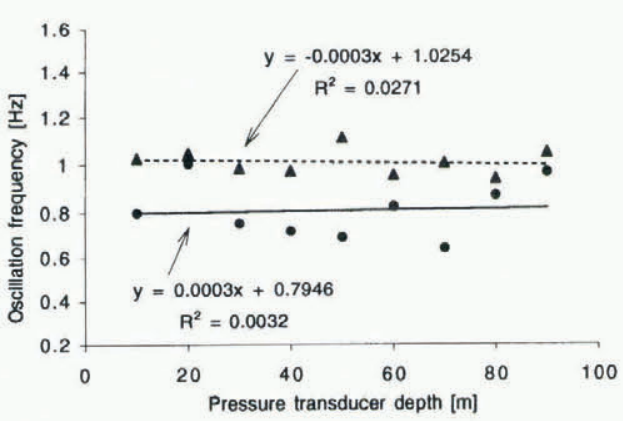

- Slug test (observed)

$\triangle$ Ball test (observed) - Slug test (regression) Bail test (regression)

Fig. 6. (a) Relative amplitude decay and (b) oscillation frequency plotted against transducer depth for repeated response tests conducted in borehole 20. Least-squares linear regression statistics are presented.

a

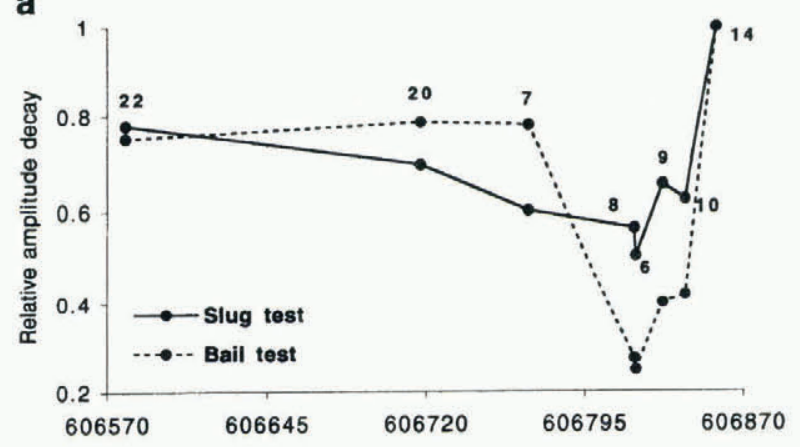

b

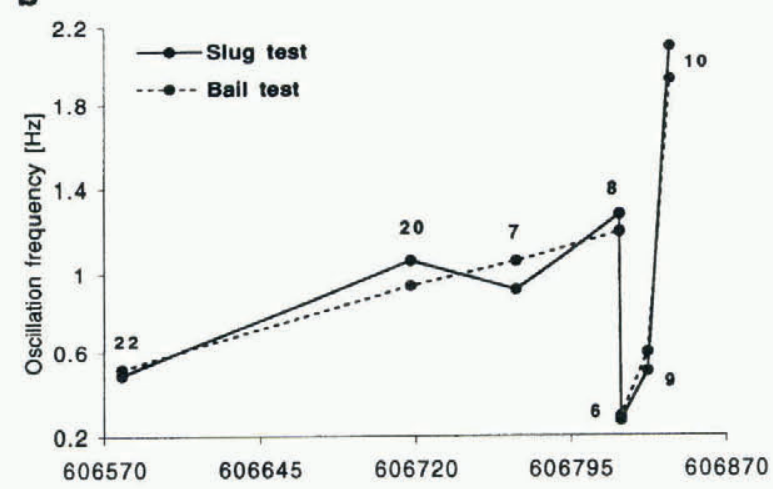

c

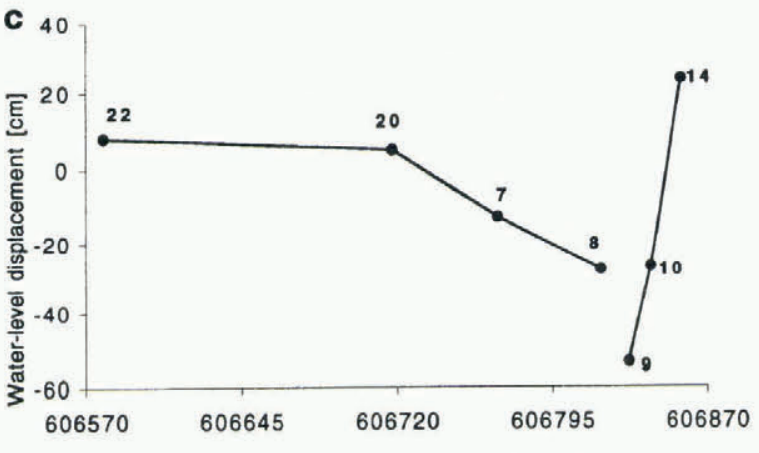

Easting (glacier bed) [Swiss grid]

Fig. 7. (a) Relative amplitude decay, (b) oscillation frequency, and (c) net water-level displacement, plotted against Easting (Swiss grid) for the impulse-test responses analyzed in the present study.

Readings for matching depths were consistent $\left(R^{2}>0.9\right)$, and observed trends were similar in all three boreholes. The most comprehensive data series was recorded in borehole 20. Test responses from this borehole indicate that relative amplitude decay decreases with increasing transducer depth for both slug $\left(R^{2}=0.87\right)$ and bail $\left(R^{2}=0.16\right)$ tests (Fig. 6). In contrast, oscillation frequencies remain stable throughout the test series, for both slug and bail tests $\left(R_{2}<0.1\right)$ (Fig. 6b). No systematic change in net water-level displacement was recorded with sensor depth.

\section{Spatial variability in response signals}

In order to assess spatial variations in the responses recorded in water-filled boreholes, parameters were averaged, separately for slug and bail tests, for all impulse tests carried out in individual boreholes (Table 1). Analysis of the results indicates a region of decreased relative amplitude decay, oscillation frequency and net water-level displacement (a maximum negative displacement) centred on Easting 606820 (Fig. 7). In each case these response minima are less than 
half the values recorded in boreholes 20 and 22, located close to the glacier centre line. This zone of minimum impulse-test response parameters coincides with the location of a major melt-season drainage channel reconstructed from glacier morphology (Sharp and others, 1993) and analysis of patterns of diurnal water-level variability late in the 1993 melt season (Hubbard and others, 1995).

\section{Secondary borehole-response signals}

Comparison of impulse-test response records from primary and secondary boreholes shows that, of the 43 dual impulse tests conducted, only one, boreholes 1 and 2, was characterised by a simultaneous secondary response (borehole 2). However, borehole inclinometer surveying indicates that these two boreholes crossed within a few metres of each other at depth. In this case, therefore, we interpret the secondary signal as a direct englacial connection rather than a subglacial communication between the two boreholes.

\section{SUMMARY AND DISGUSSION}

Analysis of relative amplitude decay, oscillation frequency and net water-level displacement for 116 impulse-test responses at Haut Glacier d'Arolla has allowed investigation of both method-related influences on response signals and spatial variations in the hydraulic system of the glacier.

Relative amplitude decay and oscillation frequency have different characteristic patterns for water-filled and fluctuating boreholes. Initial water-level displacements in waterfilled boreholes are typically an order of magnitude smaller than those recorded in fluctuating boreholes. This suggests that the two borehole types reflect different subglacial hydraulic conditions, with well-connected drainage pathways characterised by larger initial test responses.

In water-filled boreholes, relative amplitude decay and oscillation frequency are reproducible over a short timescale. In contrast, caution may need to be applied when analyzing net water-level displacements, since these are relatively irregular under apparently similar hydrological conditions. Our results therefore suggest that analysis of net water-level displacement does not provide an accurate indication of aquifer storativity beneath Haut Glacier d'Arolla.

Slug-test responses are consistent with, but not identical to, bail-test responses. This may reflect a number of causes, including (i) method-related variability in the speed of slug insertion and removal, (ii) small changes in the hydrogeological properties of the local subglacial layer caused by the water flows induced by the testing, or (iii) hydraulic differences between water flow away from the borehole base (slug test) compared with water flow towards it (bail test). Slug and bail tests may therefore reflect slightly different aquifer properties. This should be borne in mind when averaging slug- and bail-test results.

Of the three impulse-test response characteristics analyzed, oscillation frequency has the highest regression coefficient for both short-term reproducibility $\left(R^{2}=0.95\right)$ and slug- and bail-test compatibility $\left(R^{2}=0.88\right)$. Oscillation frequency is not influenced by the depth of the pressure transducer in water-filled boreholes (above). Our results therefore suggest that oscillation frequency is the most reliable and stable impulse-test response parameter at Haut Glacier d'Arolla.

The depth at which a pressure sensor is located within a water-filled borehole influences the relative amplitude decay of test response signals, but not their oscillation frequencies. The former, as defined in Equation (1), decreases with depth. Consequently, comparisons of relative amplitude decays in impulse-test response records from different boreholes should take the depth of transducer placement into account.

Spatial variations in response parameters from waterfilled boreholes coincide coherently with the location of a subglacial channel at Haut Glacier d'Arolla. This region is characterised by marked minima in all three signal parameters, suggesting that impulse-test responses from waterfilled boreholes may well reflect local subglacial hydrogeological conditions. Assuming that the water-filled boreholes analyzed in the present study have established a link to the subglacial drainage system, it is likely that their impulse-test responses reflect highly localised transmissivity variations within areas of the glacier bed that have not yet become incorporated into the area directly influenced by the nearby melt-season channel. This interpretation is consistent with the nature of the development of this channel during the 1993 melt season (evolving from a spatially heterogeneous drainage pattern into one characterised by a high degree of spatial coherence; Gordon and others, in press) and the fact that channel growth was particularly late during the inclement 1995 summer. The consistency of the correspondence between the response-parameter minima and the location of this seasonal channel strongly suggests a direct association. We therefore believe that explanations involving variations in englacial conditions or in borehole character are unlikely. Instead, local variations in hydraulic transmissivity caused by multi-seasonal eluviation of fines from a subglacial debris layer close to the inferred channel may account for the observed response-parameter minima at Haut Glacier d'Arolla.

\section{ACKNOWLEDGEMENTS}

The authors would like to thank M. Sharp, I. Willis, A. Hubbard, C. Pyle, B. Rule, A. Seagren, and S. Gordon for assisting in drilling and testing boreholes. J. Harbor and L. Copland kindly provided borehole inclinometry data. The research was supported by grants from the University of Wales, Aberystwyth, and the Nuffield Foundation. B. Kulessa is supported by a University of Wales Ph.D. studentship. We thank two anonymous reviewers for helpful comments on the manuscript.

\section{REFERENCES}

Alley, R. B. 1989. Water-pressure coupling of sliding and bed deformation: I Water system. J. Glaciol., 35(119), 108-118.

Boulton, G. S. and R. C. A. Hindmarsh. 1987. Sediment deformation beneath glaciers: rheology and geological consequences. 7. Geophys. Res. 92(B9), $9059-9082$.

Clarke, G. K. C. 1987. Subglacial till: a physical framework for its properties and processes. 7. Geophys. Res., 92(B9), 90239036.

Clarke, G. K. C., S. G. Collins and D. E. Thompson. 1984. Flow, thermal structure, and subglacial conditions of a surge-type glacier. Can. j. Earth Sci., 21 (2), 232-240.

Engelhardt, H. 1978. Water in glaciers: observations and theory of the behaviour of water levels in boreholes. Z. Gletscherkd. Glazialgeol., 14 (1), 35-60.

Ferris, J.G. and N.F. Knowles. 1954. The slug test for estimating transmissibility. U.S. Geol. Surv. Ground Water Note 26,1-7.

Gordon, S., M. Sharp, B. Hubbard, C. Smart, B. Ketterling and I. Willis. In press. Seasonal reorganisation of subglacial drainage inferred from measurements in boreholes. Hydrological Processes. 
Harper, J.T. and N. F. Humphrey. 1995. Borehole video analysis of a temperate glacier's englacial and subglacial structure: implications for glacier flow models. Geology, 23(10), 901-904.

Hodge, S. M. 1976. Direct measurement of basal water pressures: a pilot study. 7. Glaciol., 16(74), 205-218.

Hubbard, B. P., M. J. Sharp, I. C. Willis, M. K. Nielsen and C. C. Smart. 1995. Borehole water-level variations and the structure of the subglacial hydrological system of Haut Glacier d'Arolla, Valais, Switzerland. f. Glaciol., 41 (139), 572-583.

Iken, A. and R. A. Bindschadler. 1986. Combined measurements of subglacial water pressure and surface velocity at Findelengletscher, Switzerland: conclusions about drainage system and sliding mechanism. $f$. Glaciol., 32(110), 101-119.

Murray, T. and J. A. Dowdeswell. 1992. Water throughflow and the physical effects of deformation on sedimentary glacier beds. 7. Geophys. Res., 97(B6), 8993-9002.

Nye, J. F. 1973. Water at the bed of a glacier. International Association of Scientific Hydrology Publication 95 (Symposium at Cambridge 1969-Hydrology of Glaciers), 189-194.
Röthlisberger, H. 1972. Water pressure in intra- and subglacial channels. 7 . Glaciol., 11 (62), 177-203.

Shreve, R. L. 1972. Movement of water in glaciers. 7. Glaciol., 11 (62), 205-214.

Smart, C. C. 1996. Statistical evaluation of glacier boreholes as indicators of basal drainage systems. Hydrol. Processes, 10, 599 613 .

Stone, D. B. 1993. Characterization of the basal hydraulic system of a surgetype glacier: Trapridge Glacier, 1989-92. (Ph.D. thesis, University of British Columbia.)

Stone, D. B. and G. K. C. Clarke. 1993. Estimation of subglacial hydraulic properties from induced changes in basal water pressure: a theoretical framework for borehole-response tests. F. Glaciol., 39(132), 327-340.

Theis, C.V. 1935. The relation between the lowering of the piezometric surface and the rate and duration of discharge of a well using groundwater storage. Trans. Am. Geophys. Union, 2, 519-524.

Walder, J. S. 1986. Hydraulics of subglacial cavities. F. Glaciol., 32(112), 439-445.

Walder, J. S. and A. Fowler. 1994. Channelized subglacial drainage over a deformable bed. J. Glaciol., 40(134), 3-15.

Weertman, J. 1957. On the sliding of glaciers. F. Glaciol., 3(21), 33-38. 